\title{
Pengaruh Pemberian Coklat (Theobroma cacao) terhadap Kualitas Spermatozoa Tikus Wistar (Rattus norvegicus) yang Terpapar Stres
}

\author{
${ }^{1}$ Giovanna Kurnijuanto \\ ${ }^{2}$ Janette Rumbajan \\ ${ }^{2}$ Lydia E. N. Tendean
}

\author{
${ }^{1}$ Program Studi Pendidikan Dokter Fakultas Kedokteran Universitas Sam Ratulangi Manado \\ ${ }^{2}$ Bagian Biologi Fakultas Kedokteran Universitas Sam Ratulangi Manado \\ Email: gio.leung31@gmail.com
}

\begin{abstract}
A chocolate compound, flavonoid which is a subgroup of polyphenols, has protective effect on spermatozoa exposed to stress. The flavonoid compound in chocolate, (-)epicatehin, plays important roles in neutralizing ROS, blocking the production of ROS, and inhibiting enzyme activity of DNA methyltransferase. Stress activates the hypothalamuspituitary-adrenal (HPA) and simpatoadrenomedular systems that have glucocorticoid as their end product that can cause an increase in essential catabolism and trigger the production of ROS. Oxidative stress can reduce the motility of spermatozoa and cause damage to DNA of spermatozoa. This study was aimed to determine the effect of chocolate (Theobroma cacao) on the quality of spermatozoa in stressed Wistar rats (Rattus norvegicus). This was an experimental study with a post-test only control group design. Samples were spermatozoa of Wistar rats. There were 9 Wistar rats divided into 3 groups, as follows: $\mathrm{P}_{0}$ (control), $\mathrm{P}_{1}$ (stress treatment only), and $\mathrm{P}_{2}$ (stress treatment and chocolate administration). The results showed that there were no significant differences in concentration and motility, albeit, there was a significant difference in morphology of spermatozoa in Wistar rats (Rattus norvegicus). Conclusion: Chocolate (Theobroma cacao) can influence the increase of morphologic quality of spermatozoa in stressed Wistar rats.
\end{abstract}

Keywords: chocolate, stress, spermatozoa

\begin{abstract}
Abstrak: Kandungan coklat, yaitu flavonoid merupakan subgrup dari polifenol yang memiliki efek protektif terhadap spermatozoa dari paparan stres. Jenis flavonoid dalam coklat, (-)epicatehin berperan dalam menetralisir ROS, memblokir produksi ROS, dan menginhibisi aktivitas enzim DNA methyltransferase. Stres mengaktifkan sistem hipotalamus-pituitariadrenal (HPA) dan simpatoadrenomedular yang memiliki produk akhir glukokortikoid yang dapat menyebabkan peningkatan katabolisme esensial dan memicu produksi ROS. Stres oksidatif dapat menurunkan motilitas spermatozoa dan menyebabkan kerusakan DNA spermatozoa. Penelitian ini bertujuan untuk mengetahui pengaruh pemberian coklat (Theobroma cacao) terhadap kualitas spermatozoa tikus Wistar (Rattus norvegicus) yang terpapar stres. Jenis penelitian ialah eksperimental dengan post-test only control group design. Sampel penelitian ialah spermatozoa tikus Wistar (Rattus norvegicus). Dilakukan perlakuan terhadap 9 ekor tikus Wistar yang dibagi menjadi 3 kelompok, yaitu $\mathrm{P}_{0}$ (kontrol), $\mathrm{P}_{1}$ (perlakuan stres saja), dan $\mathrm{P}_{2}$ (perlakuan stres dan pemberian coklat). Hasil penelitian tidak mendapatkan perbedaan bermakna pada konsentrasi dan motilitas tetapi terdapat perbedaan bermakna pada morfologi spermatozoa tikus Wistar (Rattus norvegicus). Simpulan: Pemberian coklat (Theobroma cacao) berpengaruh terhadap peningkatan kualitas morfologi spermatozoa tikus Wistar (Rattus norvegicus) yang terpapar stres.
\end{abstract}

Kata kunci: coklat, stres, spermatozoa 
Polifenol merupakan antioksidan sekunder yang mencegah reaksi radikal bebas dan komponen seluler dengan cara menangkap radikal bebas (free radical scavenger). ${ }^{1}$ Pada sebuah studi mengenai kualitas spermatozoa, didapatkan komponen polifenol dalam coklat memiliki efek protektif terhadap spermatozoa dalam menghadapi inflamasi akut. ${ }^{2}$ Coklat kaya akan flavonoid yang merupakan subgrup dari polifenol. ${ }^{3}$ Terdapat berbagai jenis flavonoid seperti epigallocatechin gallate, genistein, apigenin, dan (-)-epicatehin. Komponen (-)epicatehin merupakan keunggulan coklat karena perannya dalam menetralisir ROS, memblokir produksi ROS, dan menginhibisi aktivitas enzim DNA methyltransferase. ${ }^{4}$ Stres merupakan respon otak dan tubuh terhadap tuntutan sehari-hari, seperti sekolah, pekerjaan, kejadiankejadian traumatik, dan lain-lain. ${ }^{5}$ Paparan kronik dari stres dapat melemahkan sistem imun dan meningkatkan risiko serangan penyakit infeksi dan memperlambat masa penyembuhan penyakit. ${ }^{6,7}$ Selain memiliki efek buruk terhadap kesehatan, stres juga memengaruhi fertilitas. Sebuah studi klinis menemukan bahwa stres menyebabkan penurunan tingkat kesuburan dan kualitas spermatozoa, kerusakan oksidatif, serta mengganggu keseimbangan oksidan dan antioksidan otak. Stres mengaktifkan sistem hipotalamus-pituitari-adrenal (HPA) dan simpatoadrenomedular yang memiliki produk akhir glukokortikoid. Glukokortikoid dapat menyebabkan peningkatan katabolisme esensial dan memicu produksi reactive oxygen species (ROS). ${ }^{8,9}$ Observasi terhadap beberapa hewan seperti tikus dan kelinci menunjukkan bahwa stres oksidatif dapat menurunkan motilitas spermatozoa dan menyebabkan kerusakan deoxyribonucleic acid (DNA) pada spermatozoa. ${ }^{10}$ Penelitian lain menyatakan bahwa level fragmentasi DNA yang tinggi berhubungan dengan penurunan motilitas, penurunan konsentrasi, dan peningkatan jumlah spermatozoa abnormal. ${ }^{11,12}$

Penelitian ini bertujuan untuk mengetahui pengaruh pemberian coklat terhadap kualitas spermatozoa tikus Wistar (Rattus norvegicus) yang terpapar stres.

\section{METODE PENELITIAN}

Jenis penelitian ini ialah eksperimental dengan post-test only control group design dan dilakukan di Laboratorium Biologi Fakultas Kedokteran Universitas Sam Ratulangi. Penelitian dilakukan selama 50 hari sejak bulan Oktober sampai Desember 2018. Sampel penelitian ini ialah tikus Wistar (Rattus norvegicus) sebanyak 9 ekor. Sebelum diberi perlakuan, tikus Wistar (Rattus norvegicus) diaklimatisasi selama 1 minggu. Perlakuan stres diberikan dengan memberikan paparan cahaya dari lampu LED yang ditempel di dalam kardus putih. Lampu dinyalakan selama 2 jam. Perlakuan stres dilakukan setiap hari selama 50 hari. Pemberian coklat dilakukan 4 kali seminggu sebanyak 1 gram. Penghitungan dosis coklat dilakukan menurut Animal Equivalent dose ${ }^{13}$ dan didapatkan dosis hasil konversi $\mathrm{x}$ BB tikus ialah 1 gram.

Tikus Wistar (Rattus norvegicus) dibagi dalam 3 kelompok secara acak yaitu kelompok kontrol, kelompok perlakuan 1 (diberi paparan stres), dan kelompok perlakuan 2 (diberi paparan stres dan coklat). Kriteria inklusi sampel ialah tikus Wistar (Rattus norvegicus) jantan berumur 12-15 minggu dan memiliki berat badan normal 150-200 gram. Kriteria eksklusi sampel ialah tikus Wistar yang tampak sakit, tidak bergerak aktif, dan mati saat penelitian.

Setelah penelitian selama 50 hari, tikus Wistar diterminasi pada hari ke-51 dan diambil sampel spermatozoa dari setiap kelompok perlakuan. Diamati kualitas spermatozoa, yaitu konsentrasi, motilitas, dan morfologi. Organ reproduksi tikus Wistar berupa testis dan kauda epididimis diambil menggunakan dissecting kit. Organ yang telah diambil kemudian dipisahkan dengan memotong bagian proksimal korpus epididimis dan bagian distal vas deferens. Setelah dipotong, kauda epididimis diletakkan di atas cawan Petri dan ditetesi larutan $\mathrm{NaCl}$ 0,9\% sebanyak 3 tetes. Pertama, harus dilakukan homogenisasi suspensi 
spermatozoa yang telah diperoleh. Untuk menghitung konsentrasi, suspensi dihisap dengan pipet leukosit sebanyak $0,5 \mathrm{ml}$, setelah itu, diencerkan dengan cairan pengencer hingga tanda 11 . Suspensi spermatozoa yang telah diencerkan diteteskan pada bilik hitung hemasitometer Improved Neubauer dan diamati di bawah mikroskop dengan pembesaran 400 kali. Penghitungan spermatozoa dilakukan dengan cara membagi satu lapang pandang menjadi empat kuadran, lalu jumlah spermatozoa yang terdapat di dalam masing-masing kuadran dihitung. Spermatozoa total di setiap kuadran dijumlahkan dan dikalikan dengan 50.000 .

Untuk memeriksa motilitas spermatozoa, suspensi spermatozoa diteteskan di atas kaca objek dengan volume tertentu yang tidak lebih dari $10 \mu$ l lalu ditutup dengan kaca penutup. Sediaan dibiarkan selama 1 menit agar stabil dan kemudian diamati dibawah mikroskop dengan pembesaran 400 kali untuk menilai motilitas spermatozoa. Morfologi spermatozoa diperiksa dengan membuat hapusan suspensi spermatozoa di atas kaca objek dan dikeringkan di udara. Sediaan difiksasi dengan metanol selama 5 menit dan dikeringkan, dilanjutkan dengan pewarnaan safranin selama 5 menit dan dibilas dengan air mengalir hingga air bilasan tidak berwarna. Setelah itu, dilakukan pewarnaan dengan kristal violet selama 1 menit. Sediaan dibilas kembali hingga air bilasan tidak berwarna. Setelah proses pewarnaan, sediaan dikeringkan lalu diamati dibawah mikroskop dengan pembesaran 100 kali dan 400 kali. Diamati 3 lapangan pandang untuk menentukan persentase morfologi spermatozoa normal dan abnormal, bentuk atau kelainan spermatozoa pada setiap lapangan pandang.

Seluruh data yang diperoleh dimasukkan ke dalam tabel dan dianalisis menggunakan aplikasi statistik. Uji komparablitas dilakukan dengan Independent T-test jika distribusi data normal dan homogen. Data dinyatakan bermakna secara statistik bila nilai $P<0,05$. Jika didapatkan data yang tidak normal dan tidak homogen maka uji komparabilitas dilakukan dengan MannWhitney test.

\section{HASIL PENELITIAN}

Tabel 1 memperlihatkan perbedaan rerata konsentrasi spermatozoa dari kelompok $\mathrm{P}_{0}, \mathrm{P}_{1}$, dan $\mathrm{P}_{2}$. Kelompok $\mathrm{P}_{0}$ memiliki rerata konsentrasi sebesar 54,4 x $10^{6}$ spermatozoa/mL; kelompok $\mathrm{P}_{1}$ memili-ki rerata konsentrasi spermatozoa sebesar $46,5 \times 10^{6}$ spermatozoa/mL; dan kelompok $\mathrm{P}_{2}$ memiliki rerata konsentrasi spermatozoa sebesar 33x $10^{6}$ spermatozoa/ mL.

Tabel 1. Konsentrasi spermatozoa

\begin{tabular}{cc}
\hline $\begin{array}{c}\text { Kelompok } \\
\text { sampel }\end{array}$ & $\begin{array}{c}\text { Konsentrasi } \\
(\mathbf{x ~ 1 0} \% \mathbf{m L})\end{array}$ \\
\hline $\mathrm{P}_{0}$ & 54,4 \\
$\mathrm{P}_{1}$ & 46,5 \\
$\mathrm{P}_{2}$ & 33 \\
\hline
\end{tabular}

Tabel 2 memperlihatkan rerata motilitas spermatozoa dari kelompok $\mathrm{P}_{0}, \mathrm{P}_{1}$, dan $\mathrm{P}_{2}$. Kelompok $\mathrm{P}_{0}$ memiliki rerata persentase motilitas normal sebesar $87,7 \%$ dan motilitas abnormal sebesar $12,3 \%$. Kelompok $\mathrm{P}_{1}$ memiliki rerata persentase motilitas normal sebesar $42,7 \%$ dan motilitas abnormal sebesar 57,3\%, sedangkan kelompok $\mathrm{P}_{2}$ memiliki rerata persentase motilitas normal sebesar $81,7 \%$ dan motilitas abnormal sebesar $18,3 \%$.

Tabel 2. Motilitas spermatozoa

\begin{tabular}{ccc}
\hline $\begin{array}{c}\text { Kelompok } \\
\text { sampel }\end{array}$ & $\begin{array}{c}\text { Motilitas } \\
\text { normal } \\
(\mathbf{\%})\end{array}$ & $\begin{array}{c}\text { Motilitas } \\
\text { abnormal } \\
(\boldsymbol{\%})\end{array}$ \\
\hline $\mathrm{P}_{0}$ & 87,7 & 12,3 \\
$\mathrm{P}_{1}$ & 42,7 & 57,3 \\
$\mathrm{P}_{2}$ & 81,7 & 18,3 \\
\hline
\end{tabular}

Tabel 3 menampilkan perbedaan rerata morfologi spermatozoa dari kelompok $\mathrm{P}_{0}$, $\mathrm{P}_{1}$, dan $\mathrm{P}_{2}$. Kelompok $\mathrm{P}_{0}$ memiliki rerata persentase morfologi normal sebesar $89,6 \%$ dan morfologi abnormal sebesar 10,4\%. Kelompok $\mathrm{P}_{1}$ memiliki rerata persentase morfologi normal sebesar $95,2 \%$ dan morfologi abnormal sebesar 4,8\% sedangkan kelompok $\mathrm{P}_{2}$ memiliki rerata persentase 
morfologi normal sebesar $44,7 \%$ dan morfologi abnormal sebesar 55,3\%.

Tabel 3. Morfologi spermatozoa

\begin{tabular}{ccc}
\hline $\begin{array}{c}\text { Kelompok } \\
\text { sampel }\end{array}$ & $\begin{array}{c}\text { Morfologi } \\
\text { normal } \\
(\boldsymbol{\%})\end{array}$ & $\begin{array}{c}\text { Morfologi } \\
\text { abnormal } \\
(\boldsymbol{\%})\end{array}$ \\
\hline $\mathrm{P}_{0}$ & 89,6 & 10,4 \\
$\mathrm{P}_{1}$ & 44,7 & 55,3 \\
$\mathrm{P}_{2}$ & 95,2 & 4,8 \\
\hline
\end{tabular}

Tabel 4 menunjukkan hasil uji komparabilitas kualitas spermatozoa antara kelompok $\mathrm{P}_{1}$ dan $\mathrm{P}_{0}$ menggunakan Independent T-test yang mendapatkan nilai $P>0,05$ yang berarti tidak terdapat perbedaan bermakna pada rerata konsentrasi $(P=$ $0,693)$ dan motilitas normal $(P=0,074)$ antara kelompok $\mathrm{P}_{1}$ dan $\mathrm{P}_{0}$. Hasil uji komparabilitas morfologi antara kelompok $\mathrm{P}_{1}$ dan $\mathrm{P}_{0}$ menggunakan Mann-Whitney test mendapatkan nilai $P=0,05$.

Tabel 4. Perbandingan kualitas spermatozoa kelompok $\mathrm{P}_{1}$ terhadap kelompok $\mathrm{P}_{0}$

\begin{tabular}{cc}
\hline Kualitas spermatozoa & Nilai $\boldsymbol{P}$ \\
\hline Konsentrasi & 0,693 \\
Motilitas & 0,074 \\
Morfologi & 0,050 \\
\hline
\end{tabular}

Tabel 5 menunjukkan hasil uji komparabilitas kualitas spermatozoa antara kelompok $\mathrm{P}_{2}$ dan $\mathrm{P}_{0}$ menggunakan Independent $T$-test memiliki nilai $P>0,05$ yang berarti tidak terdapat perbedaan bermakna pada rerata konsentrasi $(P=0,205)$ dan motilitas normal $(P=0,615)$ antara kelompok $\mathrm{P}_{2}$ dan $\mathrm{P}_{0}$. Hasil uji komparabilitas morfologi antara kelompok $\mathrm{P}_{2}$ dan $\mathrm{P}_{0}$ menggunakan Mann-Whitney test tidak memiliki nilai $P<0,05$ yang berarti tidak terdapat perbedaan bermakna pada rerata morfologi antara kelompok $\mathrm{P}_{2}$ dan $\mathrm{P}_{0}$.

Tabel 6 menunjukkan hasil uji komparabilitas kualitas spermatozoa antara kelompok $\mathrm{P}_{2}$ dan $\mathrm{P}_{1}$ menggunakan Independent $T$-test memiliki nilai $P>0,05$ yang berarti tidak terdapat perbedaan bermakna pada rerata konsentrasi $(P=0,205)$ dan motilitas $(P=0,615)$. Nilai $P<0,05$ pada morfologi berarti terdapat perbedaan bermakna pada morfologi $(P=0,000)$ antara kelompok $\mathrm{P}_{2}$ dan $\mathrm{P}_{1}$.

Tabel 5. Perbandingan kualitas spermatozoa kelompok $\mathrm{P}_{2}$ terhadap kelompok $\mathrm{P}_{0}$

\begin{tabular}{cc}
\hline Kualitas spermatozoa & Nilai $\boldsymbol{P}$ \\
\hline Konsentrasi & 0,205 \\
Motilitas & 0,615 \\
Morfologi & 0,184 \\
\hline
\end{tabular}

Tabel 6. Perbandingan kualitas spermatozoa kelompok $\mathrm{P}_{2}$ terhadap kelompok $\mathrm{P}_{1}$

\begin{tabular}{lc}
\hline Kualitas spermatozoa & Nilai $\boldsymbol{P}$ \\
\hline Konsentrasi & 0,509 \\
Motilitas & 0,146 \\
Morfologi & 0,000 \\
\hline
\end{tabular}

\section{BAHASAN}

Hasil analisis kualitas spermatozoa tikus Wistar (Rattus norvegicus) pada kelompok $\mathrm{P}_{1}$ terhadap $\mathrm{P}_{0}$ memperlihatkan perbedaan bermakna dalam peningkatan morfologi abnormal pada spermatozoa tikus Wistar yang terpapar stres. Peningkatan morfologi spermatozoa abnormal ini sesuai dengan penelitian sebelumnya oleh Wright et al $^{11}$ yang menyatakan bahwa stres oksidatif dapat menyebabkan produksi ROS melebihi batas normal. Aschbacher et $\mathrm{al}^{12}$ melaporkan bahwa paparan stres menginduksi sekresi kortisol yang berfungsi untuk metabolisme pertahanan terhadap stres. Namun, reaktivitas kortisol yang tinggi pada individu dengan paparan stres kronik menyebabkan peningkatan penanda kerusakan DNA. Hal ini dapat dihubungkan dengan kerusakan lipid, protein, dan DNA spermatozoa. DHA merupakan asam lemak predominan pada spermatozoa imatur. Karena tingginya kadar dari polyunsaturated fatty acid (PUFA) ini, maka membran spermatozoa yang sedang berkembang menjadi rentan terhadap peroksidase lipid.

Hasil analisis kualitas spermatozoa tikus Wistar pada kelompok $\mathrm{P}_{2}$ terhadap $\mathrm{P}_{1}$ 
menunjukkan perbedaan bermakna dalam peningkatan morfologi abnormal pada spermatozoa tikus Wistar yang terpapar stres $(P<0,05)$. Terdapat pengaruh perlakuan terhadap morfologi spermatozoa. sesuai dengan penelitian sebelumnya oleh Agarwal et $\mathrm{al}^{14}$ yang menunjukkan kadar malondialdehid yang merupakan produk peroksidase lipid berhubungan dengan kerusakan DNA yang menyebabkan penurunan motilitas dan konsentrasi, serta peningkatan jumlah spermatozoa abnormal. Hasil penelitian Sabeti et $\mathrm{al}^{15}$ dan Atkan et al ${ }^{16}$ menyatakan terdapat korelasi positif antara peningkatan produksi ROS dan peningkatan jumlah abnormalitas spermatozoa seperti abnormalitas bentuk kepala, akrosom, bagian tengah spermatozoa, sitoplasma, dan ekor. Spermatozoa abnormal juga semakin meningkatkan produksi ROS yang merupakan masalah utama subfertilitas dan infertilitas. Hal ini disebabkan rentannya spermatozoa terhadap stres oksidatif dan kurangnya antioksidan dan enzim polimerase DNA. Dalam penelitian sebelumnya oleh Shay et $\mathrm{al}^{17}$ dinyatakan bahwa flavonoid dalam coklat, (-)-epicatechin berperan untuk menetralisir ROS, memblokir produksi ROS, dan menginhibisi aktivitas enzim DNA methyltransferase. Dengan demikian konsumsi coklat (Theobroma cacao) dapat melindungi spermatozoa dari stres oksidatif dan mencegah fragmentasi DNA spermatozoa. Hasil ini mengonfirmasi hasil $\mathrm{P}_{2}$ terhadap $\mathrm{P}_{0}$ dan $\mathrm{P}_{2}$ terhadap $\mathrm{P}_{1}$ dalam penelitian ini, yaitu tidak terdapat perbedaan bermakna dari pemberian coklat (Theobroma cacao) ke tikus Wistar (Rattus norvegicus) kelompok $\mathrm{P}_{2}$ terhadap $\mathrm{P}_{0}$.

Hasil analisis kualitas spermatozoa tikus wistar (Rattus norvegicus) pada kelompok $\mathrm{P}_{2}$ terhadap $\mathrm{P}_{0}$ tidak mendapatkan perbedaan bermakna dalam data morfologi $(P>0,05)$ atau tidak terdapat pengaruh perlakuan terhadap morfologi spermatozoa. Diperkirakan bahwa pemberian coklat memiliki pengaruh terhadap kualitas spermatozoa tikus Wistar yang terpapar stres sehingga morfologi abnormal sperma tikus Wistar yang terpapar stres menjadi normal. Hal ini sejalan dengan penelitian oleh Treichler et $\mathrm{al}^{18}$ yang menyatakan bahwa kandungan flavonoid ()-epicatechin dalam coklat (Theobroma cacao) dapat mengurangi aktivasi aksis HPA sehingga dapat mencegah peningkatan sekresi kortisol dan produksi ROS.

\section{SIMPULAN}

Berdasarkan hasil penelitian ini dapat disimpulkan bahwa pemberian coklat (Theobroma cacao) berpengaruh terhadap peningkatan kualitas morfologi spermatozoa tikus Wistar (Rattus norvegicus) yang terpapar stres.

\section{DAFTAR PUSTAKA}

1. Winarsi H. Antioksidan Alami dan Radikal Bebas. Yogyakarta: Kanisius, 2011; p. 177-185.

2. Collodel G, Moretti E, Del Vecchio MT, Biagi M, Cardinali R, Mazzi L, et al. Effect of chocolate and propol-fenol on rabbit spermatogenesis and sperm quality following bacterial lipopolysaccharide treatment. Syst Biol Reprod Med. 2014;60(4):217-26.

3. Övet B. Investigation of Antioxidant capacity and phenolic contents of chocolates in the Turkish market. [Thesis]. Ankara: Food Engineering Department, Middle East Technical University; 2015.

4. Ward L, Pasinetti GM. Recommendations for development of botanical polyphenols as "natural drugs" for promotion of resilience against stressinduced depression and cognitive impairment. NeuroMolecular Med. 2016;18(3):487-95.

5. Sadock B, Sadock V, Ruiz P. Kaplan and Sadock's Comprehensive Textbook of Psychiatry (10th ed). Lippincott Williams and Wilkins, 2017.

6. Lagraauw HM, Kuiper J, Bot I. Acute and chronic psychological stress as risk factors for cardiovascular disease: Insights gained from epidemiological, clinical and experimental studies. Brain Behav Immun. 2015;50:18-30.

7. Melmed S, Polonsky KS, Larsen PR, Kronenberg HM, editors. Williams Textbook of Endocrinology Vol. 12, Acta Endocrinologica (Bucharest). 2016. $113-113$ p. Available from: 
http://www.acta-endo.ro/Archive/ Abstract?doi=2016.113

8. Nargund VH. Effects of psychological stress on male fertility. Nat Rev Urol. 2015;12(7):373-82.

9. Juananda D, Cahyani D, Sari R, Prakosa D, Arfian N, Romi M. Pengaruh Stres kronik terhadap otak: kajian biomolekuler hormon glukokortikoid dan regulasi brain-derived neurotrophic. Faktor (BDNF) Pascastres di cerebellum. JIK. 2015;2:65-70.

10. Banks S, Dorrian J, Grant C, Coates A. Circadian misalignment and metabolic consequences: shiftwork and altered meal times. In: Modulation of Sleep by Obesity, Diabetes, Age, and Diet. Elsevier Inc, 2014; p. 155-164. Available from: http://dx.doi.org/10. 1016/B978-0-12-420168-2.00017-X

11. Wright $C$, Milne $S$, Leeson $H$. Sperm DNA damage caused by oxidative stress: modifiable clinical, lifestyle and nutritional factors in male infertility. Reprod Biomed Online. 2014;28(6): 684-703.

12. Aschbacher K, O'Donovan A, Wolkowitz OM, Dhabhar FS, Su Y, Epel E. Good stress, bad stress and oxidative stress: Insights from anticipatory cortisol reactivity. Psychoneuro- endocrinology 2013;38(9):1698-708.

13. Nair A, Jacob $\mathbf{S}$. A simple practice guide for dose conversion between animals and human. J Basic Clin Pharm. 2016; $7(2): 27$.

14. Agarwal A, Virk G, Ong C, du Plessis SS. Effect of oxidative stress on male reproduction. World J Mens Health. 2014;32(1):1.

15. Sabeti P, Pourmasumi S, Rahiminia T, Akyash F, Talebi A. Etiologies of sperm oxidative stress. Int $\mathrm{J}$ Reprod BioMed. 2016;14(4):231-40.

16. Aktan G, Doğru-Abbasoğlu S, Küçükgergin $\mathbf{C}$, Kadioğlu A, ÖzdemirlerErata G, Koçak-Toker N. Mystery of idiopathic male infertility: Is oxidative stress an actual risk? Fertil Steril. 2013;99(5):1211-5.

17. Shay J, Elbaz HA, Lee I, Zielske SP, Malek MH, Hüttemann M. Molecular mechanisms and therapeutic effects of (-)-epicatechin and other polyphenols in cancer, inflammation, diabetes, and neurodegeneration. Oxid Med Cell Longev. 2015;2015: 181260.

18. Treichler MSS, Kuebler BSU, Huber S. Dark chocolate intake buffers stress reactivity in humans. J Am Coll Cardiol. 2014;63(21):2297-9. 